\title{
Modeling growth and yield of chickpea (Cicer arietinum L.)
}

\author{
Piara Singh *, S.M. Virmani \\ Soils and Agroclimatology Division, International Crops Research Institute for the Semi-Arid Tropics (ICRISAT), P.O. Patancheru 502 324, \\ Andhra Pradesh, India
}

Received 16 May 1995; accepted 14 October 1995

\begin{abstract}
A chickpea (Cicer arietinum L.) growth and development model (CHIKPGRO) has been developed from the hedgerowversion of the groundnut model PNUTGRO. Changes were made in various subroutines determining vegetative and reproductive development, crop growth and partitioning of assimilates to component plant organs to simulate chickpea crop growth under water-limiting and nonlimiting situations. Using the experimental data of the 1984 and 1986 seasons, the model was calibrated for cultivar-specific parameters of cvs. Annigeri and JG74 and also for soil parameters determining water balance of the root-zone. The model was validated against data from the 1985, 1987, 1992 and 1993 seasons. The model predicted flowering, pod initiation, beginning of seed growth and physiological maturity within \pm 5 days of the observed values, except under extreme wet situations when the actual seed growth and physiological maturity of chickpea occurred later than the simulated dates. Leaf area index, total dry matter production (TDM) and its partitioning to various plant organs under irrigated and water-stressed conditions were also predicted satisfactorily by the model. Soil moisture changes in the rooting-zone of chickpea were also predicted accurately. Predicted TDM and seed yields of cvs. Annigeri and JG 74 at harvest were significantly correlated with the observed data $\left(r^{2}=0.89\right.$ and RMSE $=0.34 \mathrm{t} /$ ha for TDM; $r^{2}=0.82$ and RMSE $=0.14 \mathrm{t} / \mathrm{ha}$ for seed). These results show that CHIKPGRO can be used to predict potential and water-limited yields of chickpea in the Indian plateau. Future work requires inclusion of a soil fertility submodel and model testing over a wide range of environments.
\end{abstract}

Keywords: Chickpea; Cicer arietinum; Development; Growth; Modelling; Yield

\section{Introduction}

Chickpea (Cicer arietinum L.) is grown over a wide range of agroclimatic environments. It is traditionally grown in the northern hemisphere mostly between $20^{\circ} \mathrm{N}$ and $40^{\circ} \mathrm{N}$ latitude. Most of the desi (with yellow to brown seed testa) chickpea is grown

\footnotetext{
* Corresponding author.
}

between $20^{\circ} \mathrm{N}$ and $30^{\circ} \mathrm{N}$, while kabuli (with cream colored seed testa) types are grown above $30^{\circ} \mathrm{N}$. There is a small area under this crop between $10^{\circ} \mathrm{N}$ and $20^{\circ} \mathrm{N}$ at relatively high elevations in India and Ethiopia (Khanna-Chopra and Sinha, 1987).

In the mediterranean region $\left(30^{\circ} \mathrm{N}\right.$ to $\left.43^{\circ} \mathrm{N}\right)$ both temperature and daylength increase (9.4 to $13.4 \mathrm{~h}$ ) from the time of sowing of spring chickpea. Most of the rainfall is received in the early part of crop growth. Cold temperature, low radiation and wet seed beds are the major constraints during the vege- 
tative period and drought during the reproductive period. However, winter-sown chickpea is exposed to relatively less favorable thermal and better moisture regimes than spring-sown chickpea (Saxena, 1981). In the northern part of the Indian subcontinent and Central America $\left(20^{\circ} \mathrm{N}\right.$ to $\left.30^{\circ} \mathrm{N}\right)$ temperature and daylength decrease until flowering begins, but increase during pod development. The crop is grown on stored soil moisture, and drought and low temperatures are the primary factors limiting growth. In East Africa and the Indian plateau $\left(8^{\circ} \mathrm{N}\right.$ to $\left.20^{\circ} \mathrm{N}\right)$, daylength and temperature are relatively constant during the season. The crop is raised essentially on stored soil moisture from preceding rain. High temperature and drought are the major constraints to chickpea production in these environments (Khanna-Chopra and Sinha, 1987).

The three major physical factors that influence the phenology, growth and productivity of chickpea are daylength, temperature and water availability, of which the latter two are highly variable in these environments. To extrapolate the research results of field experiments in time and space and to assess the potential of new technologies or cultivars in new environments, we need to integrate various growth and development processes of chickpea to develop a chickpea yield simulation model. Sufficient information is available in literature on the response of vegetative and reproductive development of chickpea to environmental factors (Roberts et al., 1980; Summerfield et al., 1980; Covell et al., 1986), which can be used to develop predictive models of chickpea phenology. However, the growth and senescence response of chickpea (such as development of canopy and root systems, assimilate production and partitioning, and senescence and mobilization of assimilates) to environmental factors has not been adequately studied and reported in a way which is useful for developing response functions needed for the chickpea model. As chickpea and groundnut are legumes, they have more similarity than differences in their growth and development processes. Therefore, some of the parameters and response functions that have not been investigated for chickpea could be taken from the groundnut model. To accomplish this we used the hedgerow version of groundnut model, PNUTGRO, which was earlier developed by Boote et al. $(1987,1992)$ at the University of Florida, USA. A good feature of the groundnut model is that it has a generic soil water balance submodel which can simulate soil water balance of a crop provided the cropspecific parameters have been substituted. This model also has a hedgerow subroutine to simulate the influence of row-spacing and plant population on light interception and photosynthesis. PNUTGRO has a modular structure, user-friendly interfaces and graphic outputs for visual display of simulated and observed data, which made it easy to modify the model and test its performance.

This paper describes various soil, climatic, crop growth and development processes considered necessary to develop the chickpea model, hereafter referred to as CHIKPGRO, and presents the model performance in simulating growth and development of chickpea, and soil water dynamics in the root zone under irrigated and nonirrigated situations in a semiarid tropical environment of India.

\section{Model description}

To develop the chickpea model, we used the source-code of the hedgerow version of PNUTGRO (Boote et al., 1992) as much as possible. General guidelines developed by Boote and Jones (1988) were followed to adapt PNUTGRO to simulate chickpea growth and development. The model does not consider biological nitrogen fixation by chickpea and assumes soil fertility to be nonlimiting for crop growth. It also does not incorporate the effect of diseases and pests on crop growth and yield. Various soil and plant processes considered and the changes made in various subroutines and files of PNUTGRO to develop the chickpea model are given in Appendix A and described in the following sub-sections.

\subsection{Soil-water balance and root system}

The soil-water subroutine in chickpea model is the same as in the PNUTGRO model (Ritchie, 1985). It predicts soil water flow and water uptake for each soil horizon or set of soil layers within a horizon. Root growth is handled similarly as in PNUTGRO. Total root length is determined by the carbohydrate partitioned to roots and the root length-to-weight parameter (RFAC1). Partitioning to roots was changed for chickpea, but the same RFACl of 4550 


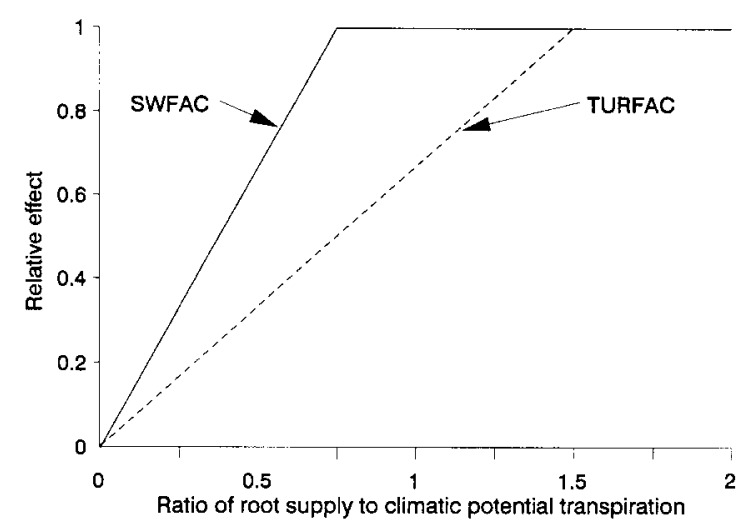

Fig. 1. Relationship of turgor factor TURFAC and soil water stress factor SWFAC to the ratio of water supply by roots to the demand as potential transpiration.

$\mathrm{cm}$ root length $/ \mathrm{g}$ was used. The distribution of roots in the soil zones depends on current root depth, soil water in each zone and an empirical weighting function (WR(L)) that represents the probability distribution of roots growing in each zone late in the season if well-watered. This function accounts for horizon effects on root growth as well as genetic differences. The rate of root-depth increase ( $\mathrm{RFAC2}=3.0$ $\mathrm{cm} /$ physiological day) continues until a maximum soil- and crop-limited rooting depth is reached.

Based upon the ratio of water supply by the roots to the water demand as potential transpiration, two water stress factors, TURFAC and SWFAC, are estimated in the water balance subroutine to influence various plant processes (Fig. 1). Turgor factor TURFAC is equal to 1.0 when the ratio of supply to demand is equal to or greater than 1.5 and decreases linearly to 0.0 as the ratio decreases from 1.5 to 0.0 . Soil water stress factor SWFAC, which is less sensitive than TURFAC, is used to influence leaf photosynthesis. SWFAC is equal to 1.0 when the ratio of water supply to demand is more than or equal to 0.75 and decreases linearly to 0.0 as this ratio decreases from 0.75 to 0.0 . The SWFAC response function for chickpea was developed by model calibration using the data on dry matter production rates under water stress.

\subsection{Crop phenology}

The prediction of crop development and ontogeny is important because the onset of new organs dictates where assimilate is partitioned. The vegetative and reproductive stages of chickpea are defined in the same manner as for groundnut (Boote, 1982), except that chickpea does not have the peg-initiation stage as defined for groundnut. Therefore, the reproductive stages for chickpea are defined as flowering, pod initiation, full-pod, initiation of seed growth, fullseed, physiological maturity and harvest maturity. The stages of vegetative and reproductive development influence canopy height-width increase, partitioning among plant parts, pod addition, seed addition and beginning of $\mathrm{N}$ mobilization.

The rate of vegetative stage ( $\mathrm{V}$-stage) progression (increase in the number of nodes on the main stem) is assumed to have a linear response to temperature. Vegetative development in chickpea has a base temperature of $0^{\circ} \mathrm{C}$ (Siddique et al., 1983; Ellis et al., 1986). The optimum temperature for chickpea development has been variously reported (van der Maesen, 1972; Covell et al., 1986) and is assumed to range between 20 to $32^{\circ} \mathrm{C}$ in the model. Therefore, the rate of $\mathrm{V}$-stage progression in the chickpea model is 0.0 at $0^{\circ} \mathrm{C}$, linearly increases to 1.0 between 20 and $32^{\circ} \mathrm{C}$ and decreases above $32^{\circ} \mathrm{C}$ to 0.0 at $55^{\circ} \mathrm{C}$ (Fig. 2).

Unlike groundnut, chickpea is a long-day plant (Roberts et al., 1980; Summerfield et al., 1980, 1981). Other major factors which affect reproductive

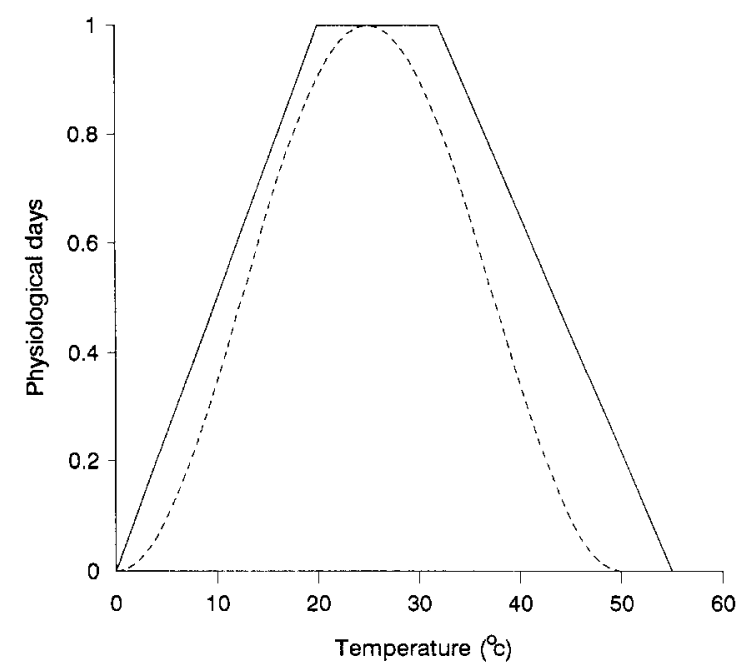

Fig. 2. Relationship between physiological days per real day and temperature used in CHIKPGRO for V-stage progression (solid line) and reproductive development (broken line). 

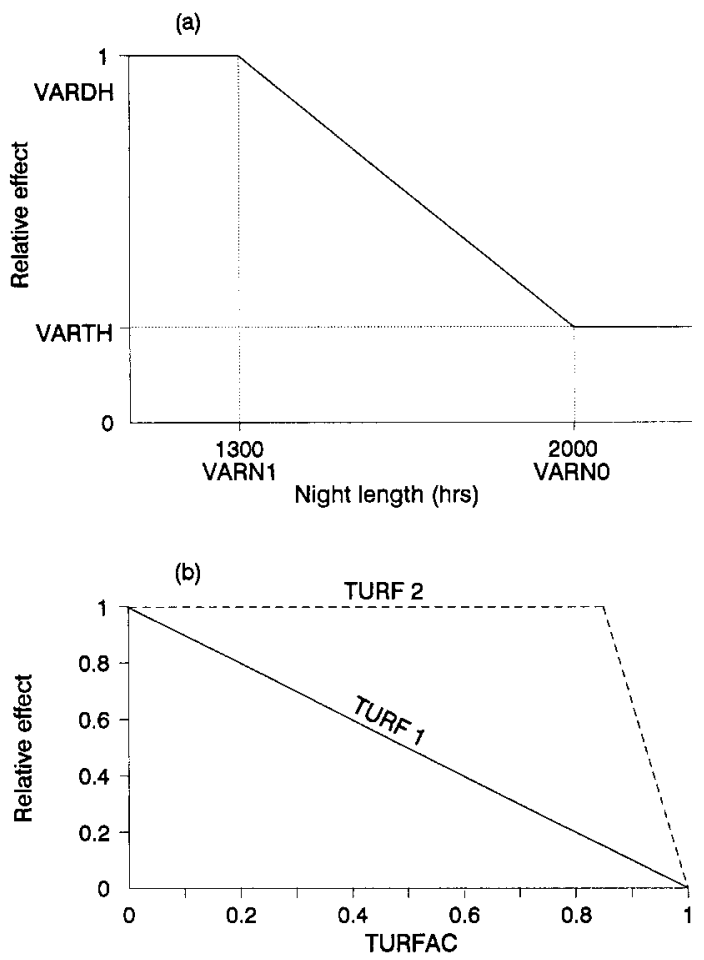

Fig. 3. Response functions for (a) nightlength effect on flowering and (b) water stress effect on reproductive development in chickpea (see Sections 2.2 and 4.2 and Appendix A for the explanation of abbreviations).

development in chickpea are temperature and water stress. Reproductive development (flowering, pod initiation, beginning of seed growth and maturity) in chickpea is assumed to follow a half-sine function with a base temperature of $0^{\circ} \mathrm{C}$ and optimum temperature of $25^{\circ} \mathrm{C}$ (Fig. 2). Photoperiod is assumed to affect only the emergence-to-flowering phase and follows the function depicted in the Fig. 3a. If the nightlength is equal to or less than $13 \mathrm{~h}$ (VARN1), the relative rate of development is maximum, i.e., 1.0. Above $13 \mathrm{~h}$ the relative rate decreases linearly to a cultivar-specific minimum value at nightlength of $20 \mathrm{~h}$ (VARNO). Water stress in chickpea hastens reproductive development, which is proportional to the amount of stress experienced by the crop. Water-stress response functions TURF1 and TURF2 affecting chickpea phenology were related to TURFAC (Fig. 3b) and added to the crop parameters file.
TURF2 is used to affect the duration of flowering to pod-initiation phase, whereas TURF1 is used to affect vegetative stage- 1 to flowering and pod initiation to harvest maturity. Cultivar differences in sensitivity to water stress are achieved by a stress factor (STRCON) defined in the genetics file.

\subsection{Biomass production}

\subsubsection{Photosynthesis}

Daily photosynthesis by the chickpea model is computed as in the hedgerow version of the PNUTGRO model (Boote et al., 1989, 1992; Boote and Loomis, 1991). The approach considers two classes of leaves: sunlit and shaded. Hourly leaf photosynthesis of sunlit and shaded leaves is computed using the asymptotic exponential equation defined by a maximum light-saturated rate (PMAX) and quantum efficiency $(\mathrm{QE})$. Hourly leaf photosynthesis is summed over all leaf area in sunlit and shaded classes of leaves to compute hourly canopy assimilation. Hourly assimilation is accumulated to give daily rates.

Response to temperature. Photosynthesis response to temperature in the chickpea model is computed as in PNUTGRo (Boote et al., 1987, 1992). The relative response of PMAX to temperature increases from 0.0 at $5^{\circ} \mathrm{C}$ to relative rate of 0.9 at $25^{\circ} \mathrm{C}$. From $25^{\circ} \mathrm{C}$ it achieves an optimum of 1.0 between $28^{\circ} \mathrm{C}$ and $34^{\circ} \mathrm{C}$ and declines above $34^{\circ} \mathrm{C}$.

Response to leaf $N$ concentration. The shape of the leaf photosynthesis response to leaf $\mathrm{N}$ concentration is the same as in PNUTGRo. Leaf PMAX response to $\mathrm{N}$ is modeled with a half parabola described by a minimum $\mathrm{N}$ concentration (Nbase $=$ $2.2 \% \mathrm{~N}$ ) at which photosynthesis is zero and an $\mathrm{N}$ concentration (Nopt $=5.0 \% \mathrm{~N}$ ) at which photosynthesis is maximum. Leaf $\mathrm{N}$ concentrations are based on the analysis of chickpea leaves (cv. Annigeri) sampled during peak growth prior to pod initiation and at physiological maturity. However, data on the shape of the photosynthesis response curve was not available and is assumed the same as in PNUTGRO.

Response to soil moisture availability. Soil moisture availability in the model is computed in the water balance subroutine (WATBAL.FOR). Leaf photosynthesis is influenced by the soil water stress factor SWFAC as described in Section 2.1 (see Fig. 1). 
Response to soil fertility. At present the chickpea model does not incorporate the effect of soil fertility and symbiotic $\mathrm{N}$ fixation on crop growth and development, and assumes that nutrient availability is not a limiting factor for crop growth. A growth reduction factor, referred to as PHFAC3, is introduced in the photosynthesis subroutine to reduce crop growth because of poor soil physical condition, suboptimal soil fertility, disease or pests present throughout the crop growth period. The value of PHFAC3 can be set between 0.0 and 1.0 to match the modeled maximum crop growth rates with the observed data from the no water-stress situation.

\subsubsection{Height-width prediction}

The hedgerow photosynthesis model requires the prediction of canopy geometry. Because of the similarity in the growth habit of chickpea and groundnut, the canopy height and width of chickpea in the model is computed in the same fashion as in PNUTGRO. The rate of height and width increase is proportional to the rate of $\mathrm{V}$-stage increase, which in turn is dependent on temperature and water deficit. The chickpea model uses the same functions as in the PNUTGRO model which describe internode length relative to progressive $\mathrm{V}$-stage development. The chickpea model uses the relative height and width (RHIGH or RWIDTH) modifiers of PNUTGRO to account for the differences in growth habit of chickpea cultivars which may affect light interception and photosynthesis.

\subsubsection{Respiration and cost of tissue synthesis}

Maintenance respiration in chickpea depends upon temperature, crop photosynthesis rate and on current crop biomass (root + leaf + stem + pod). It is computed in the same manner as in the PNUTGRO model. Growth respiration and the efficiency of conversion of glucose to plant tissue is computed using the approach of Penning de Vries and van Laar (1982, pp. 123-125), assuming that approximate tissue composition is known. Leaf, stem, pod wall and seeds of chickpea were analyzed for carbohydrate, protein, lipid and ash content. This analysis was done on plant samples taken prior to active pod-fill when most of the vegetative tissue had been produced, but before protein mobilization had started. Lignin and organic acid content were assumed to be the same as for the groundnut tissue (Boote et al., 1986). Composition of roots was also considered the same as for groundnut.

The estimated cost to synthesize chickpea seed is $1.39 \mathrm{~g}$ glucose $/ \mathrm{g}$ seed including $\mathrm{N}$ assimilation, and $0.97 \mathrm{~g}$ glucose $/ \mathrm{g}$ seed where amides are available from protein mobilization. Chickpea seeds are much less costly to make than the groundnut seeds because of smaller lipid content. Estimated costs to synthesize leaf, stem, root and pod wall are 1.36, 1.30, 1.32 and $1.39 \mathrm{~g}$ of glucose $/ \mathrm{g}$ of tissue, respectively.

\subsection{Partitioning of biomass}

\subsubsection{Vegetative growth and partitioning}

Vegetative growth in chickpea consists of leaf, stem plus petiole and root growth from emergence through maturity. Partitioning of assimilates to these tissues depends on the stage of growth but also varies with drought stress. New growth of leaves, stems and roots are calculated by the equation

$$
\mathrm{Xi} * \mathrm{E}(\mathrm{Pg}-\mathrm{Rm})
$$

where Xi represents partitioning factors for leaves, stems and roots, $E$ is conversion efficiency for photosynthate, $\mathrm{Pg}$ is gross photosynthesis rate $\left(\mathrm{g} \mathrm{CH}_{2} \mathrm{O}\right.$ day $^{-1} \mathrm{~m}^{-2}$ ) and $\mathrm{Rm}$ is the maintenance respiration rate. $\mathrm{Xi}$ values for partitioning to vegetative tissues are computed from the proportion of growth that goes to vegetative tissue ( 1 - XPOD) multiplied by the fraction of vegetative tissue which is to go to leaves (FRLF), stems (FRSTM) and roots (FRRT). Values for FRLF, FRSTM and FRRT are input as a function of V-stage. After NDLEAF (the day of maximum number of $V$-stage), the relative partitioning among vegetative tissue is constant to maturity.

Until pod set, all assimilate goes to vegetative tissue. As the pods (and seeds) are added, they have first priority over the assimilate and progressively reduce the amount of growth going to vegetative components. To mimic chickpea growth, assimilate partitioning to pods (pod wall + seed) was limited to a maximum of 0.90 at which point no pods are added. Maximum value of partitioning to fruits (XFRUIT) is genotype specific. Very little leaf area is added in chickpea after pod set is complete and seed growth has commenced. 
Effect of drought on leaf expansion and partitioning. Partitioning between roots and tops (leaves and stems) and leaf expansion in chickpea is influenced by drought stress. As TURFAC drops below 1.0, a certain fraction (ATOP) of assimilate normally partitioned to leaves and stems is diverted to roots. We presently assume that ATOP can be up to 1.0 if TURFAC drops to 0.0. In addition to altered partitioning to root and shoot, TURFAC acts to reduce leaf expansion. Since leaf expansion is more sensitive to water stress in chickpea than in groundnut, the relative leaf area expansion factor decreases from 1.0 to 0.0 as TURFAC decreases from 1.0 to 0.7 . The effect is to allow leaves to grow in dry weight but not as much in leaf area. Thus the leaves thicken and specific leaf area (SLA) decreases.

Changes in specific leaf area during the season. Specific leaf area (SLA) is the ratio of leaf area to leaf mass. SLA of new-produced leaves is primarily a function of phenological stage and secondarily dependent on TURFAC.

\subsubsection{Reproductive growth and partitioning}

Pod addition and growth. Dry weight accumulation in flowers is considered negligible in chickpea. Pod addition begins after flowering at pod-initiation stage. The rates of pod addition and growth are computed in the same way as in PNUTGRO. The actual number of pods added on a given day $(\mathrm{SH})$ depends on maximum rate of pod addition (PODMAX) times the ratio of actual to maximum photosynthesis (PG/PHTMAX) and the heat units (ACCDAY) accrued on that day.

$\operatorname{SH}(0, \mathrm{t})$

$=\operatorname{Min}\left\{\begin{array}{l}\text { PODMAX } *(\text { PG } / \text { PHTMAX }) * \text { ACCDAY } \\ \text { PGLEFT } /(\text { GRRATI } * \text { AGRSH })\end{array}\right.$

PGLEFT is the carbohydrate remaining after existing seeds and pods grow, after vegetative tissue grows its minimum ( 1 - XFRUIT), and after maintenance respiration is subtracted. The GRRATI is the temperature-limited maximum growth rate of pod wall per pod per day and AGRSH is the glucose required to make a gram of pod wall. When partitioning to existing pods (pod wall + seed) exceeds XFRUIT (here 0.90), pod addition ceases.
The pods added each day are grown and aged as separate groups. Pod wall of each pod formed on a given day grow for LNGSH days (d) during which they add weight as limited by GRRATI, temperature and available carbohydrate after supplying to seeds and maintenance respiration. Water stress in chickpea decreases the number of pods per plant and number of seeds per pod (Sivakumar and Singh, 1987). However, under water stress, vegetative growth is suppressed and assimilate partition to pods is increased which hastens maturity in chickpea (Singh, 1991).

Seed growth. Seed growth rate is a function of available assimilate supply (multiplied by XFRUIT), temperature (TMPFAC) and cultivar-specific individual seed growth rates. Cultivar-specific seed and pod wall maximum growth rates (SDMAXR and SHMAXR) are inputs to the model. The SDMAXR and SHMAXR are multiplied by a temperature factor (TMPFAC) to determine the potential growth rates for seeds and pod walls. The TMPFAC varies from 0 to 1.0 where the "normalized" shape of the temperature function is considered the same as for groundnut. If sufficient assimilate is available, seeds will grow at their potential rate as set by TMPFAC.

Protein mobilization from vegetative tissue is simulated to begin as soon as seeds are formed. Both the mobilized and the newly assimilated protein is used to grow chickpea seeds following the same procedure as in PNUTGRo (Boote et al., 1987).

Crop maturation. Seed growth continues until either of following two events occur. Seed growth ceases when the ratio of seed to pod weight reaches a cultivar-specific maximum seed/pod fraction. Alternatively, seed growth can be terminated by the loss of photosynthetic capacity caused by disease, insects, severe drought and frost.

\subsection{Senescence}

Leaf senescence is caused by crop aging, drought stress and protein remobilization. Prior to beginning of seed growth, senescence is based on a table of cumulative percent senesced leaf weight as a function of V-stage for fully irrigated plants. This feature is similar to PNUTGRO in that normal leaf senescence starts at V-5 and increases linearly to $12 \%$ of cumulative leaf weight by $\mathrm{V}-14$ and $16 \%$ by $\mathrm{V}-30$. If 
drought stress occurs, leaf senescence may exceed that described above. The maximum limit on leaf senescence due to drought stress (SENMAX) begins at 0.0 at $\mathrm{V}-3$, reaches 0.20 at $\mathrm{V}-5$, increases linearly to 0.60 by $\mathrm{V}-10$ and can be 0.60 after $\mathrm{V}-10$ to maturity. The variable SENDAY determines the maximum fraction of existing leaf weight to senesce on a severe drought-stress day when TURFAC is low. Actual senescence is delayed by 4 days from the time of drought stress (lag of 4 days) because leaves take time to die and abscise.

Chickpea, unlike groundnut, has a grand senescence phase, triggered at physiological maturity (PM). This occurs even in well-irrigated situations, perhaps because the overall $\mathrm{N}$ content of the canopy is normally very low at PM and many leaves reach minimum $\mathrm{N}$ level at the same time. At present, the leaf senescence factor (SENRT2) is set equal to 0.20, i.e., $20 \%$ of the leaf weight senesces per day after PM. This is based upon the model calibration with chickpea cultivar Annigeri.

Protein mobilization. Protein mobilization in chickpea begins as soon as seed growth begins. This feature is the same as in PNUTGRO. Mobilization increases for several weeks while seed number increases and thereby increases the total seed-growth capacity to use the available amides. New vegetative growth continues to add new protein to the protein pool even while protein is mobilized from existing leaves. The net effect is to reduce the vegetative protein composition even while vegetative dry weight is increasing. For each $\mathrm{g}$ of protein mobilized from leaves SENRTE $g$ of leaves are abscised, in addition to the weight of protein lost. Since senescence in chickpea is more marked than in groundnut, the value of SENRTE was increased from 1.0 to 2.0. If leaves senesce prior to the start of protein mobilization, or abscise due to drought stress, the mobilizable protein in those leaves is also lost from the available protein pool.

The amount of protein available for mobilization from leaf, stem, shell and root is computed using initial and minimum protein fractions. Initial and minimum protein fractions in $\mathrm{g} / \mathrm{g}$ of tissue dry weight are 0.317 and 0.166 for leaf, 0.148 and 0.042 for stem, 0.137 and 0.094 for root, and 0.150 and 0.069 for pod wall. These values are based upon analyses of cultivar Annigeri.

\section{Material and methods}

\subsection{Field experiments}

Field experiments were conducted during the 1984 to 1987,1992 and 1993 post rainy seasons at the ICRISAT center (lat. $17^{\circ} 30^{\prime} \mathrm{N}$, long. $78^{\circ} 16^{\prime} \mathrm{E}$; alt. $549 \mathrm{~m}$ ) on a Vertisol to study the influence of moisture regimes on phenology, growth, yield and water uptake by chickpea. The experimental details and the observations taken are described below:

The 1984 experiment. In 1984 rabi season three chickpea cultivars (Annigeri, K 850 and G 130) were sown in a split-plot experiment. The main treatments were irrigated and nonirrigated treatments. Each replication was divided into two blocks $(21.6 \times 12.0$ $\mathrm{m})$ to which the main treatments were randomly assigned. The main treatment plots were further divided into three equal subplots to which the subtreatments (chickpea cultivars) were randomly assigned. The experiment was replicated three times. The field was prepared in ridges and furrows. Each ridge had two rows of chickpea such that the spacing between rows was $30 \mathrm{~cm}$. Sowing was on 5 November and seedlings emerged on 15 November 1984. Plant population maintained after thinning was 30 plants $/ \mathrm{m}^{2}$. Fertilizer was applied at the rate of $18 \mathrm{~kg}$ $\mathrm{N} /$ ha and $20 \mathrm{~kg} \mathrm{P} / \mathrm{ha}$ as diammonium phosphate at sowing. Total rainfall during the crop growth period was $8.0 \mathrm{~mm}$. The nonirrigated treatment received 45 $\mathrm{mm}$ irrigation at sowing and no irrigation thereafter. The irrigated treatment received nine irrigations during the crop growth period at 7- to 10-day intervals. Total irrigation applied was $382 \mathrm{~mm}$ to Annigeri, $362 \mathrm{~mm}$ to $\mathrm{K} 850$ and $357 \mathrm{~mm}$ to $\mathrm{G} 130$. Irrigation was applied using perforated pipes.

The crop was protected from diseases and pests and was harvested on 12 February 1985 in the nonirrigated treatment and on 11 March 1985 in the irrigated treatment.

The 1985 experiment. This experiment was conducted to study the response to various intensities of water deficit at different phenophases of chickpea using the line-source irrigation technique. The experiment consisted of 4 main $\times 3$ sub-treatments. The main treatments were: $\mathrm{T} 1$, gradient irrigation during all phenophases; $\mathrm{T} 2$, gradient irrigation during emergence to flowering and uniform irrigation during 
other phenophases; T3, gradient irrigation from $50 \%$ flowering to beginning of pod-fill and uniform irrigation during other phenophases; $\mathrm{T} 4$, gradient irrigation from beginning pod-fill to physiological maturity and uniform irrigation during other phenophases.

The field was prepared in ridges and furrows. Main plots $(9 \times 18 \mathrm{~m})$ were laid out on either side of the line-source sprinkler pipeline such that the amount of irrigation applied decreased away from the sprinkler pipeline. Each main plot was further divided into three equal size subplots $(9 \times 6 \mathrm{~m})$ to define three moisture regimes: M1, M2 and M3 in decreasing order of irrigation amount received. Uniform irrigation was given to the crop using perforated pipes. Cultivar Annigeri was sown on 5 November 1985 such that each ridge had two chickpea rows 30 $\mathrm{cm}$ apart. The seedlings emerged on 15 November, 1985. Plant population was 30 plants $/ \mathrm{m}^{2}$. Fertilizer was applied before sowing at the rate of $20 \mathrm{~kg} \mathrm{~N} / \mathrm{ha}$ and $40 \mathrm{~kg} \mathrm{P} / \mathrm{ha}$ as diammonium phosphate and single super phosphate. The experiment was replicated three times. Total irrigation given to the 12 treatments ranged from 45 to $227 \mathrm{~mm}$ during the crop growth period. Total rainfall received during the crop growth period was $105 \mathrm{~mm}$. The crop was protected from diseases and pests. Harvesting was done on 10 March 1986.

The 1986 experiment. The 1986 experiment had the same treatments (total $=12$ ) and the experimental design as the 1985 experiment. Chickpea variety JG 74 was sown on 30 October 1986 and emerged on 7 November 1986. Field preparation, plant population, row-spacing and method of irrigation were the same as in 1985. Prior to sowing, fertilizer was applied at the rate of $18 \mathrm{~kg} \mathrm{~N} / \mathrm{ha}$ and $20 \mathrm{~kg} \mathrm{P} / \mathrm{ha}$ as diammonium phosphate. Subplot size was $21.6 \mathrm{~m}^{2}$. Amount of irrigation given to the 12 treatments ranged from 49 to $313 \mathrm{~mm}$. Total rainfall received during the crop growth period was $48 \mathrm{~mm}$. The crop was protected from diseases and pests. The crop was harvested on 27 March 1987.

The 1987 experiment. The design and treatments were the same as for the 1986 season experiment. Cultivar JG 74 was sown on 28 October 1987 and emerged on 5 November. Subplot size was $14.4 \mathrm{~m}^{2}$. Plant population, row-spacing, rates of fertilizer application, the method of irrigation and the number of replications were the same as in 1986. Amount of irrigation applied to various treatments ranged from 25 to $247 \mathrm{~mm}$. Total rainfall received during the crop growth period was $241 \mathrm{~mm}$. The crop was harvested on 16 February 1988.

The 1992 experiment. This was a split-plot experiment consisting of irrigated and nonirrigated treatments as the main treatments, which were randomly assigned to the two main blocks in a replication. Each main-treatment block was further divided into six equal subplots to which six cultivars (ICCV 88202, Annigeri, ICCC 32, ICCC 42, ICCV 2 and ICCV 10) were randomly assigned. The experiment was replicated four times. Each subplot size was $60 \mathrm{~m}^{2}$. The field was prepared to broad beds and furrows. Fertilizer at the rate of $18 \mathrm{~kg} \mathrm{~N} /$ ha and 15 $\mathrm{kg} \mathrm{P} / \mathrm{ha}$ was applied as diammonium phosphate at sowing. Sowing was done on 3 November 1992. Plant population maintained after thinning was 30 plants $/ \mathrm{m}^{2}$. Row-spacing was $30 \mathrm{~cm}$. Both the irrigated and nonirrigated treatments received $80 \mathrm{~mm}$ of irrigation at sowing to facilitate germination. Irrigated treatment was watered at 7- to 10-day intervals. Irrigation was given using perforated pipes and the amount of irrigation given was measured using catch-cans. Total irrigation given to the irrigated treatment was $448 \mathrm{~mm}$. Total rainfall received during the crop growth period was $77 \mathrm{~mm}$. The crop was intensively protected from diseases and pests. The crop was harvested on 4 March 1993.

The 1993 experiment. During 1993 post rainy season six cultivars of chickpea (ICCV 88202, Annigeri, ICCC 32, ICCC 42, ICCV 2 and ICCV 10) were grown under rainfed conditions after an initial irrigation of $55 \mathrm{~mm}$ at sowing to facilitate germination. The design of experiment was a randomized complete block replicated four times. Plot size was $48 \mathrm{~m}^{2}$. The field was prepared to broad beds and furrows and fertilizer at the rate of $18 \mathrm{~kg} \mathrm{~N} / \mathrm{ha}$ and $15 \mathrm{~kg} \mathrm{P} / \mathrm{ha}$ was applied as diammonium phosphate at sowing. Sowing was done on 11 November 1993. Row-spacing was $30 \mathrm{~cm}$ and plant population maintained after thinning was 30 plants $/ \mathrm{m}^{2}$. Total rainfall received during the crop growth period was 31 $\mathrm{mm}$. The crop was frequently sprayed against diseases and pests, however complete control was not possible. All cultivars were harvested on 17 February, except ICCV 32 which was harvested on 28 February 1994. 
Table 1

Characteristics of the soils, initial profile water content at sowing and the value of PHFAC3 for various seasons. Abbreviations and units as in the text (see Section 4.1)

\begin{tabular}{llllllll}
\hline Season & $\mathrm{U}$ & SWCON & $\mathrm{CN}_{2}$ & TSW $_{\mathrm{LL}}{ }^{\mathrm{a}}$ & TSW $_{\text {DUL }}$ & TSW $_{\text {IN }}^{c}$ & PHFAC3 $^{c}$ \\
\hline 1984 & 6.0 & 0.70 & 95 & 300 & 475 & 475 & 0.775 \\
1985 & 6.0 & 0.70 & 95 & 300 & 475 & 409 & 0.775 \\
1986 & 6.0 & 0.70 & 95 & 300 & 475 & 475 & 0.775 \\
1987 & 6.0 & 0.70 & 95 & 300 & 475 & 457 & 0.775 \\
1992 & 6.0 & 0.40 & 93 & 560 & 820 & 783 & $0.99 \mathrm{~d}$ \\
1993 & 6.0 & 0.40 & 93 & 560 & 820 & 791 & $0.93 \mathrm{~d}$ \\
\hline
\end{tabular}

${ }^{a} \mathrm{TSW}_{\mathrm{LL}}=$ Total soil water content in the rooting zone at the lower limit of water extraction (mm).

${ }^{\mathrm{h}} \mathrm{TSW}_{\mathrm{DUL}}=$ Total soil water content in the rooting zone at the upper drained limit $(\mathrm{mm})$.

c $\mathrm{TSW}_{\mathrm{IN}}=$ Initial soil water content in the rooting zone $(\mathrm{mm})$.

${ }^{d}$ Pre-sowing $\mathrm{NO}_{3}-\mathrm{N}, \mathrm{P}$ and $\mathrm{K}$ contents in the top $30 \mathrm{~cm}$ of soil were 64,48 and $600 \mathrm{~kg} /$ ha, respectively, for the 1992 season; and 30,20 and $750 \mathrm{~kg}$ / ha, respectively, for the 1993 season.

\subsection{Measurements}

Crop phenology. Vegetative stages (V-stages) were recorded as the number of nodes formed on the main stem of the chickpea plant. The crop was considered to have reached a particular growth stage when $50 \%$ of the plants had shown that stage of development. The reproductive stages observed were, flowering, pod initiation, beginning of seed growth, full-seed and physiological maturity. Phenological observations were taken on at least 5 plants per plot at 4-5-day intervals.

Growth analysis. Plant samples were taken from each plot at 7- to 10-day intervals. Area harvested was $0.3 \mathrm{~m}^{2}$ per plot for the 1984 to 1987 season experiments and $0.75 \mathrm{~m}^{2}$ per plot for 1992 and 1993 seasons. The number of replications sampled were at least three in all years. To determine leaf area and partition of dry matter, plant components such as leaves, stems, pods, seeds and pod walls were separated and oven dried at $60^{\circ} \mathrm{C}$ for 3 to 4 days and weighed. Leaf area was determined using a leaf area meter (LI-191SB; LI-COR Ltd.).

Soil moisture. Soil moisture was recorded at weekly to 10-day intervals using a neutron probe. At least one access tube was installed in each plot and observations were taken at $15-\mathrm{cm}$ depth intervals starting at $30 \mathrm{~cm}$ depth to $150 \mathrm{~cm}$. Soil moisture in the $0-10$ and $10-22.5 \mathrm{~cm}$ layers was determined gravimetrically.

Yields at harvest. Total dry matter, pod and seed yields were recorded in all replications of the experiments. Area harvested ranged from 9 to $27 \mathrm{~m}^{2}$ for various experiments. Dry weight of pods, seeds and stalks were determined by oven drying either the whole harvest of each plot or a sub-sample. Drying procedure was the same as for growth analysis.

Weather data. All the weather data required for model execution were obtained from the meteorological observatory situated about half a kilometer away from the experimental site. The database management program of the Decision Support System for Agrotechnology Transfer (DSSAT) (IBSNAT, 1989) was used to create the climate, crop and soil data files required for model execution.

\section{Model calibration}

Cultivar Annigeri was sown during the 1984, 1985, 1992 and 1993 post rainy seasons, whereas cultivar JG 74 was sown during 1986 and 1987 post rainy seasons. In 1984 to 1987 the experiments were conducted on a low water-holding capacity Vertisol ( $175 \mathrm{~mm}$ extractable water) while in 1992 and 1993 the experiments were conducted on a high waterholding capacity Vertisol $(260 \mathrm{~mm}$ extractable water) (Table 1). Data obtained in the 1984 and 1986 seasons were used to calibrate the soil parameters and to determine the genetic coefficients of cvs. 
Annigeri and JG 74. Data of the remaining seasons were used for model validation. The calibration procedure followed is described below.

\subsection{Soil parameters}

Soil survey data on mechanical composition and associated parameters were collected from the location to create the soil file required by the model using the soils-data-retrieval program of DSSAT (IBSNAT, 1989). The program estimates bare soil albedo, upper limit of stage-1 evaporation (U, mm), soil water drainage coefficient (SWCON, fraction drained per day), USDA-SCS curve number (CN2, 0 to 100), coefficients in the steady-state solution to the radial flow root water uptake equation (SWCON1, SWCON2 and SWCON3, all in $\mathrm{cm}^{3} / \mathrm{cm}^{3}$ ) and max- imum daily root water uptake per unit root length (RWUMX, $\mathrm{cm}^{3} / \mathrm{cm} / \mathrm{d}$ ) (Jones and Kiniry, 1986). The program also estimates for each layer the lower limit of plant extractable water (LL, $\mathrm{cm}^{3} / \mathrm{cm}^{3}$ ), drained upper limit of soil water content (DUL, $\mathrm{cm}^{3} / \mathrm{cm}^{3}$ ), saturated water content (SAT, $\mathrm{cm}^{3} / \mathrm{cm}^{3}$ ), root distribution weighting factor (WR) and moist bulk density of soil $\left(\mathrm{BD}, \mathrm{g} / \mathrm{cm}^{3}\right)$. The soil parameters thus obtained required calibration against the data on soil moisture changes during the season such that the observed soil moisture changes were close to the simulated data.

\subsection{Genetic coefficients}

Both phenology and growth coefficients of cvs. Annigeri and JG74 cultivars were determined by

Table 2

Genetic coefficients of cultivars Annigeri and JG 74 obtained by calibration against the 1984 and 1986 seasons data

\begin{tabular}{|c|c|c|}
\hline Description & Annigeri & $\mathrm{JG} 74$ \\
\hline \multicolumn{3}{|l|}{ A. Crop phenology } \\
\hline \multicolumn{3}{|l|}{ Physiological days from: } \\
\hline Sowing to emergence, VARTHR(1) & 4.0 & 4.0 \\
\hline Emergence to vegetative stage $1, \operatorname{VARTHR}(2)$ & 6.0 & 6.0 \\
\hline Vegetative stage 1 to flowering, VARTHR(5) & 29.0 & 41.0 \\
\hline Flowering to beginning of pod growth, VARTHR(6) & 8.0 & 8.0 \\
\hline Beginning of pod growth to beginning of seed growth, LAGSD & 20.0 & 20.0 \\
\hline Flowering to end of node addition, NDLEAF & 37.0 & 26.0 \\
\hline Flowering to physiological maturity, VARTHR(10) & 49.0 & 41.0 \\
\hline Physiological maturity to harvest maturity, VARTHR(11) & 5.0 & 5.0 \\
\hline \multicolumn{3}{|l|}{ B. Vegetative growth coefficients } \\
\hline Number of trifoliates produced per physiological day, TRIFOL & 0.60 & 0.60 \\
\hline Leaf size at nodes 8 to $10, \operatorname{SIZELF}\left(\mathrm{cm}^{2} /\right.$ leaf $)$ & $10.0^{\mathrm{a}}$ & $10.0^{\mathrm{a}}$ \\
\hline SLA of new growth during peak vegetative growth, SLAVAR $\left(\mathrm{cm}^{2} / \mathrm{g}\right)$ & $180.0^{\mathrm{a}}$ & $180.0^{\mathrm{a}}$ \\
\hline Fraction of available protein pool mobilized per physiological day, CNMOB & $0.036^{\mathrm{b}}$ & $0.036^{b}$ \\
\hline Maximum leaf photosynthesis rate, $\operatorname{PGLF}\left(\mathrm{mg} \mathrm{CO} \mathrm{m}^{-2} \mathrm{~s}^{-1}\right)$ & $1.7^{\mathrm{b}}$ & $1.7^{b}$ \\
\hline Relative canopy width, RWIDTH & $1.0^{\mathrm{b}}$ & $1.0^{\mathrm{b}}$ \\
\hline Relative canopy height, RHIGH & $1.0^{\mathrm{b}}$ & $1.0^{\mathrm{b}}$ \\
\hline \multicolumn{3}{|l|}{ C. Reproductive growth coefficients } \\
\hline Number of seeds per pod, SDPDVR & $1.2^{\mathrm{a}}$ & $1.6^{\mathrm{a}}$ \\
\hline Maximum seed to pod ratio, THRESH (\%) & $85.0^{\mathrm{a}}$ & $73.0^{\mathrm{a}}$ \\
\hline Length of the time an individual pod-wall may grow; LNGSH (physiological days) & 5.0 & 5.5 \\
\hline Maximum growth rate per pod-wall, SHVAR (mg/day) & 6.5 & 10.5 \\
\hline Maximum growth rate per seed, SDVAR (mg/day) & 5.5 & 10.0 \\
\hline Maximum pod addition rate, PODVAR (pods / physiological day) & 95.0 & 90.0 \\
\hline Maximum fraction of daily available assimilates allowed to go to pods, XFRUIT & 0.90 & 0.90 \\
\hline \multicolumn{3}{|l|}{ D. Miscellaneous } \\
\hline Water stress sensitivity coefficient, STRCON (unitless) & 1.0 & 2.0 \\
\hline
\end{tabular}

\footnotetext{
${ }^{a}$ Determined from the actual data of these cultivars.
}

${ }^{b}$ Assumed the same as in PNUTGRO. 
comparing the model predictions against the growth and development data of the cultivars (Table 2). Data from the irrigated (nonstressed) and nonirrigated treatments of the 1984 and 1986 season experiments were used for this purpose. The coefficients related to the timing of various growth stages were calibrated in a chronological order. These coefficients were: VARTHR(1) to adjust days to emergence, $\operatorname{VARTHR}(2)$ for first leaf appearance, VARTHR(5) for flowering, VARTHR(6) for beginning of pod growth, LAGSD for beginning of seed growth, VARTHR(10) for physiological maturity and VARTHR(11) for harvest maturity. Values of these coefficients were set for the model to predict various growth stages. Cultivar sensitivity to water stress for hastening of phenological events (flowering, podding, beginning seed and maturity) was set by changing STRCON.
The rate of vegetative progression and specific leaf area (SLA) were calibrated by changing values of TRIFOL and SLAVAR, respectively. SLAVAR was adjusted such that simulated peak SLA matched observed SLA values. Rate of pod and seed addition were set by altering pod addition rate (PODVAR) and number of seeds per pod.

Pod wall growth was calibrated by adjusting values of pod wall growth rate (SHVAR) and the duration of pod wall growth (LNGSH). Seed growth was calibrated by changing values of seed growth rate coefficient (SDVAR). Finally the simulated harvest index was matched with the actual harvest index by changing XFRUIT and PODVAR. To calibrate the cultivar for photoperiod sensitivity for pod addition and pod growth rate, VARN1 and VARN0 were set at 13 and $20 \mathrm{~h}$ of nightlength, respectively (Fig. 3a). Decreasing VARTH from 1.0 to a lesser value

Table 3

Total rainfall and mean monthly maximum and minimum temperatures, solar radiation and open-pan evaporation during various seasons of the experiment

\begin{tabular}{|c|c|c|c|c|c|}
\hline Month & $\begin{array}{l}\text { Rainfall } \\
(\mathrm{mm})\end{array}$ & $\begin{array}{l}\text { Maximum temperature } \\
\left({ }^{\circ} \mathrm{C}\right)\end{array}$ & $\begin{array}{l}\text { Minimum temperature } \\
\left({ }^{\circ} \mathrm{C}\right)\end{array}$ & $\begin{array}{l}\text { Solar radiation } \\
\left(\mathrm{MJ} \mathrm{m}^{-2} \mathrm{day}^{-1}\right)\end{array}$ & $\begin{array}{l}\text { Open-pan evaporation } \\
\left(\mathrm{mm} \text { day }^{-1}\right)\end{array}$ \\
\hline \multicolumn{6}{|l|}{1985} \\
\hline Nov & 0.0 & 29.0 & 13.4 & 17.5 & 5.5 \\
\hline Dec & 8.1 & 28.6 & 13.3 & 15.8 & 5.1 \\
\hline Jan & 53.1 & 27.0 & 13.4 & 16.2 & 4.9 \\
\hline Feb & 43.6 & 30.3 & 17.4 & 19.1 & 6.6 \\
\hline Mar & 0.0 & 35.1 & 20.1 & 22.3 & 9.4 \\
\hline \multicolumn{6}{|l|}{1987} \\
\hline Nov & 240.0 & 27.5 & 18.0 & 13.6 & 3.6 \\
\hline Dec & 0.8 & 26.9 & 14.2 & 15.1 & 3.8 \\
\hline Jan & 0.0 & 28.4 & 14.1 & 16.9 & 4.6 \\
\hline Feb & 4.0 & 32.0 & 17.4 & 17.5 & 6.1 \\
\hline Mar & 0.0 & 35.0 & 20.2 & 20.2 & 8.4 \\
\hline \multicolumn{6}{|l|}{1992} \\
\hline Nov & 77.0 & 28.5 & 17.9 & 15.4 & 4.5 \\
\hline Dec & 0.0 & 26.8 & 11.7 & 17.2 & 4.0 \\
\hline Jan & 0.0 & 30.2 & 12.7 & 17.6 & 5.1 \\
\hline Feb & 0.0 & 30.9 & 14.0 & 20.5 & 6.7 \\
\hline Mar & 0.5 & 34.5 & 19.7 & 21.6 & 8.7 \\
\hline \multicolumn{6}{|l|}{1993} \\
\hline Nov & 0.0 & 29.1 & 15.1 & 18.0 & 4.8 \\
\hline Dec & 29.0 & 26.2 & 11.9 & 15.4 & 3.6 \\
\hline Jan & 1.8 & 28.6 & 14.4 & 16.5 & 4.3 \\
\hline Feb & 5.6 & 31.5 & 17.4 & 19.6 & 6.4 \\
\hline Mar & 0.0 & 36.8 & 19.4 & 22.1 & 8.5 \\
\hline
\end{tabular}


allowed nightlength greater than $13 \mathrm{~h}$ to delay pod growth and decrease partitioning to the reproductive organs and vice-versa.

\section{Model validation}

The model was validated against the crop growth, phenology and soil moisture data of the 1985,1987 . 1992 and 1993 seasons. The seasons primarily differed in the timing and amount of rainfall received during the crop growth period (Table 3 ). The general trend in other climatic elements was similar in all seasons. The 1987 data were for cultivar JG 74 and for other seasons for cv. Annigeri. Soil parameters and genetic coefficients determined earlier using the 1984 and 1986 data were fixed and not changed during validation. The soil type during the 1992 and 1993 seasons was, however, a high water-holding capacity Vertisol and of different soil quality. The factor PHFAC3 required recalibration and was set at 0.99 and 0.93 for the 1992 and 1993 seasons, respectively. Greater value of PHFAC3 for the 1992 season is because of better pre-sowing fertility status of the soil than during 1993 (Table 1). Data sets of 1992 and 1993 seasons were useful for additional validation of the model to simulate growth and development processes of chickpea.

Vegetative development. The model was tested against the 1992 and 1993 data for cv. Annigeri. The rate of $\mathrm{V}$-stage progression was accurately predicted

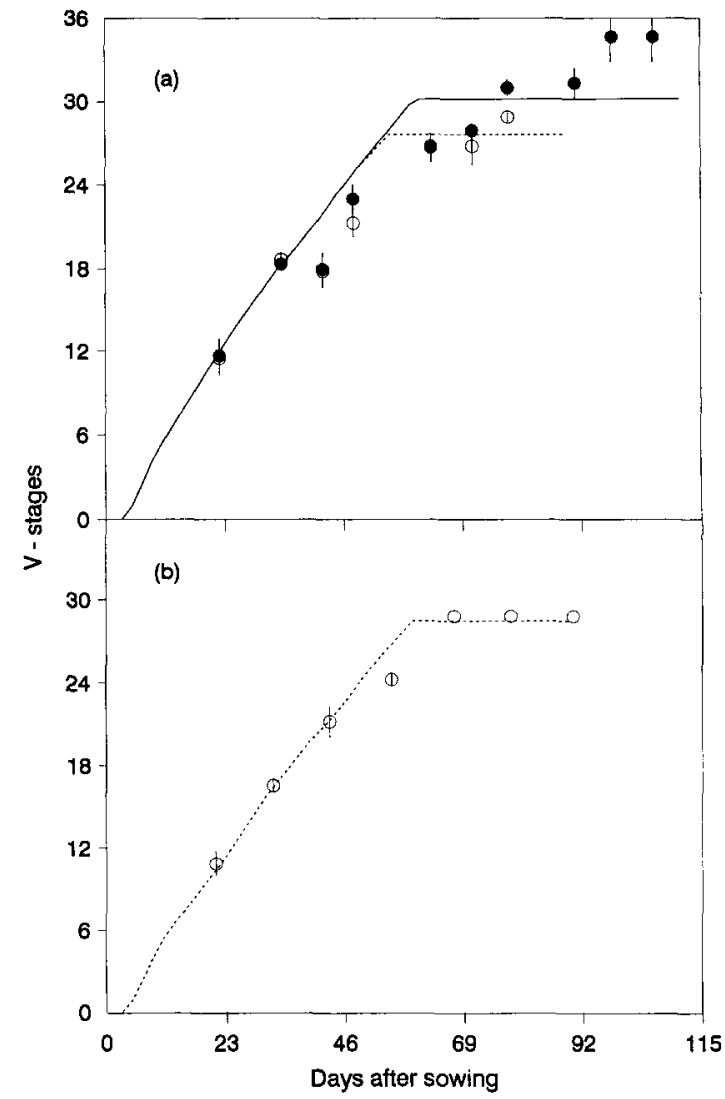

Fig. 4. Simulated (lines) and observed (data points) V-stage progression during (a) 1992 season in the irrigated (O-solid line) and nonirrigated ( $\mathrm{O}$-broken line) treatments and (b) during 1993 season in the nonirrigated treatment. Vertical bars are twice the standard error of mean

Table 4

Observed $(\mathrm{O})$ and simulated minus observed $(\mathrm{S}-\mathrm{O})$ days to flowering, pod initiation, beginning of seed growth and physiological maturity of chickpea cultivars in the irrigated (IR) and nonirrigated (NI) treatments during various seasons

\begin{tabular}{|c|c|c|c|c|c|c|c|c|c|c|}
\hline \multirow[t]{2}{*}{ Season } & & & \multirow{2}{*}{$\frac{\text { Treatment }}{\mathrm{O}}$} & \multirow{2}{*}{$\frac{\text { Cultivar }}{\mathrm{S}-\mathrm{O}}$} & \multirow{2}{*}{ Flowering } & \multirow{2}{*}{$\frac{\text { Pod initiation }}{S-O}$} & \multicolumn{2}{|c|}{ Beginning seed } & \multicolumn{2}{|c|}{ Physiological maturity } \\
\hline & & & & & & & $\mathrm{O}$ & $s-o$ & $\mathrm{O}$ & $S-O$ \\
\hline \multirow[t]{2}{*}{1985} & IR & Annigeri & 42 & 0 & 46 & 2 & 67 & -9 & 114 & -10 \\
\hline & NI & & 42 & -1 & 45 & 3 & 60 & -5 & 99 & -6 \\
\hline \multirow[t]{2}{*}{1987} & IR & JG 74 & 50 & 1 & 57 & 1 & 72 & -4 & 110 & -3 \\
\hline & NI & & 50 & 0 & 52 & 3 & 63 & 2 & 92 & -5 \\
\hline \multirow[t]{2}{*}{1992} & IR & Annigeri & 39 & -1 & 44 & 0 & 71 & -18 & 111 & -6 \\
\hline & NI & & 38 & 0 & 44 & 0 & 48 & 3 & 89 & 1 \\
\hline 1993 & NI & Annigeri & 46 & -3 & 52 & -2 & 55 & 1 & 89 & 3 \\
\hline \multicolumn{4}{|c|}{ Root mean square error $( \pm)$} & 1.3 & & 2.0 & & 8.1 & & 5.5 \\
\hline
\end{tabular}


by the model for both the irrigated and water-stressed situations, however, the number of V-stages finally achieved in the irrigated treatment was underestimated (Fig. 4a and b). This discrepancy may be attributed to the error in predicting the beginning and rate of seed growth (Table 4). These results indicate that the functions used to predict $\mathrm{V}$-stage development are satisfactory, i.e., 0.60 nodes are produced per physiological day using the base temperature of $0^{\circ} \mathrm{C}$ and optimum range of 20 to $32^{\circ} \mathrm{C}$.

Reproductive development. Days to flowering and pod initiation were predicted within \pm 3 days of observed values for the cultivars Annigeri and JG 74 (Table 4). However, the error was more in predicting initiation of seed growth and physiological maturity

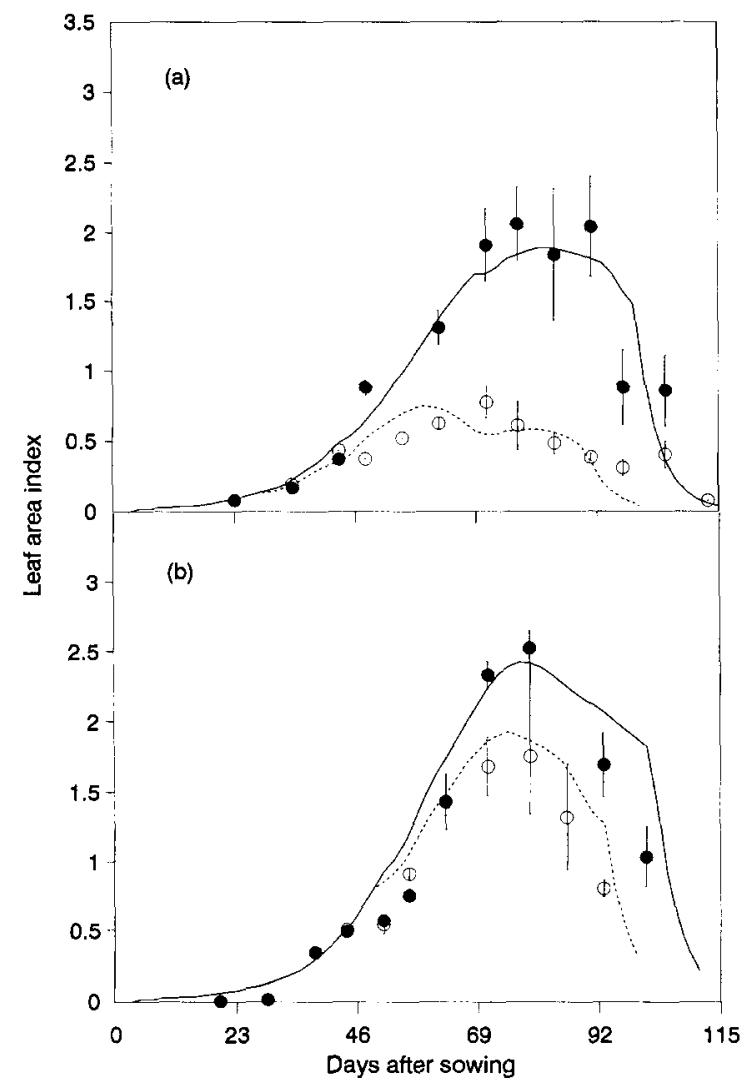

Fig. 5. Simulated (lines) and observed (data points) leaf area index in the irrigated ( - -solid line) and water-stressed ( $O$-broken line) treatments during (a) 1985 and (b) 1987 seasons. Vertical bars are twice the standard error of mean.

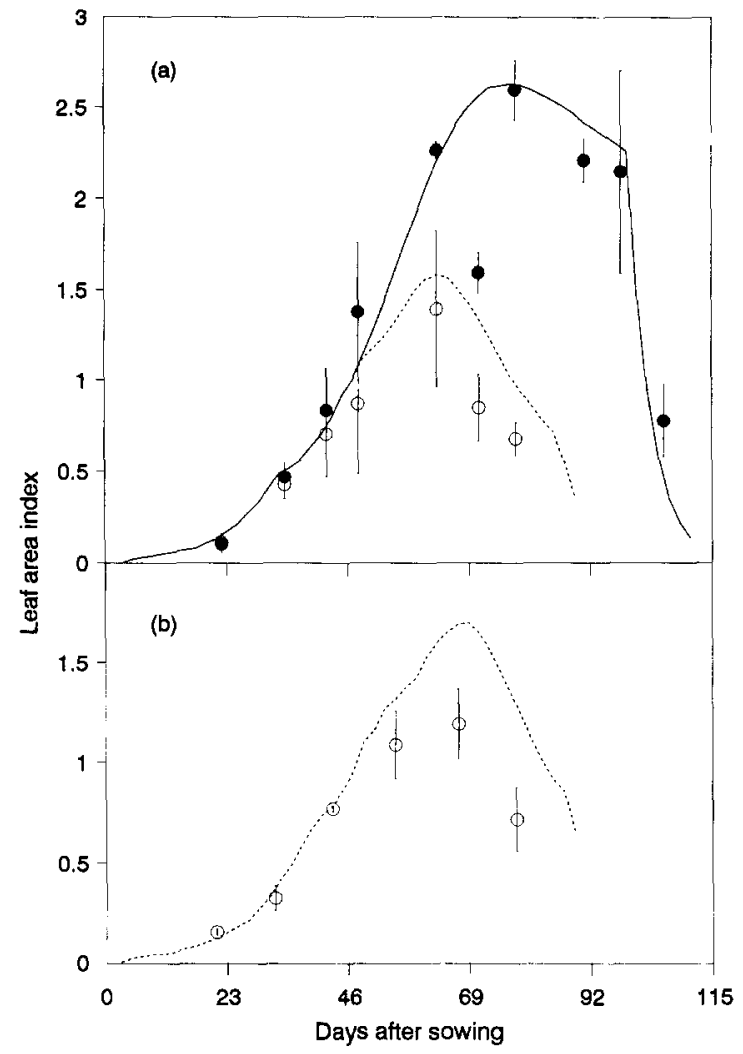

Fig. 6. Simulated (lines) and observed (data points) leaf are index during (a) 1992 season in the irrigated ( - -solid line) and nonirrigated (O-broken line) treatments and during (b) 1993 season in the nonirrigated treatment. Vertical bars are twice the standard error of mean.

especially in the irrigated situation. This is a characteristic of the chickpea crop that under wetter conditions, pod-filling and maturity are delayed. This may be attributed to some microclimatic factors that are influenced by irrigation and not considered in the model. The data obtained at Patancheru were not suitable to test the model for the influence of photoperiod on reproductive development. KhannaChopra and Sinha (1987) reported that low temperature, high humidity, overcast sky and wet seed beds delay the initiation of pods in the north Indian conditions. Because of the lack of these response functions it was not possible to test the chickpea response to such weather conditions. Accurate prediction of reproductive stages by the model indicates 
that temperature and water-stress functions used to predict reproductive phenology are satisfactory. The model may need recalibration for photoperiodic sensitivity coefficients at higher latitudes where photoperiod during the season is less than optimum.

Canopy development. Prediction of canopy development (leaf area index) and its decay due to crop maturity and water stress was fairly accurate during the 1985 and 1987 seasons under irrigated and water-stress situations (Fig. 5). Discrepancy between observed and simulated LAI for these two seasons may be attributed to the variation in soil fertility between the seasons. Predictions of LAI were better for the 1992 and 1993 seasons after the adjustments

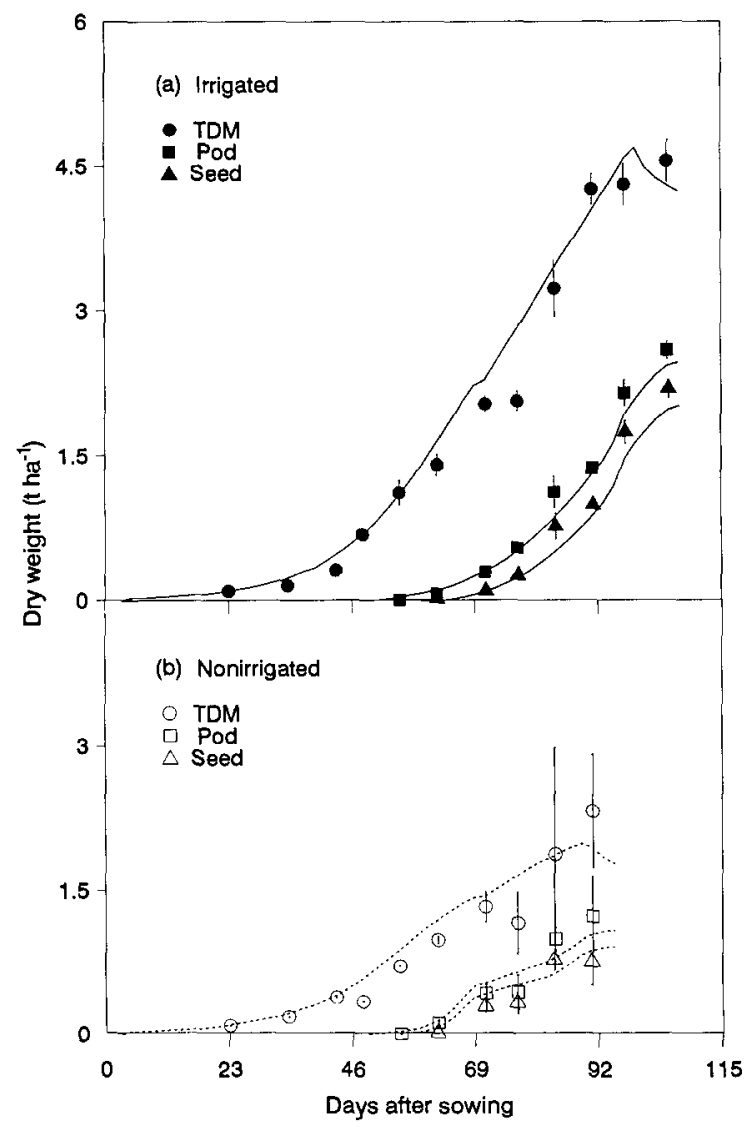

Fig. 7. Simulated (lines) and observed (data points) total dry matter (TDM), pod and seed weights during the 1985 season in the (a) irrigated and (b) nonirrigated treatments. Vertical bars are twice the standard error of mean.

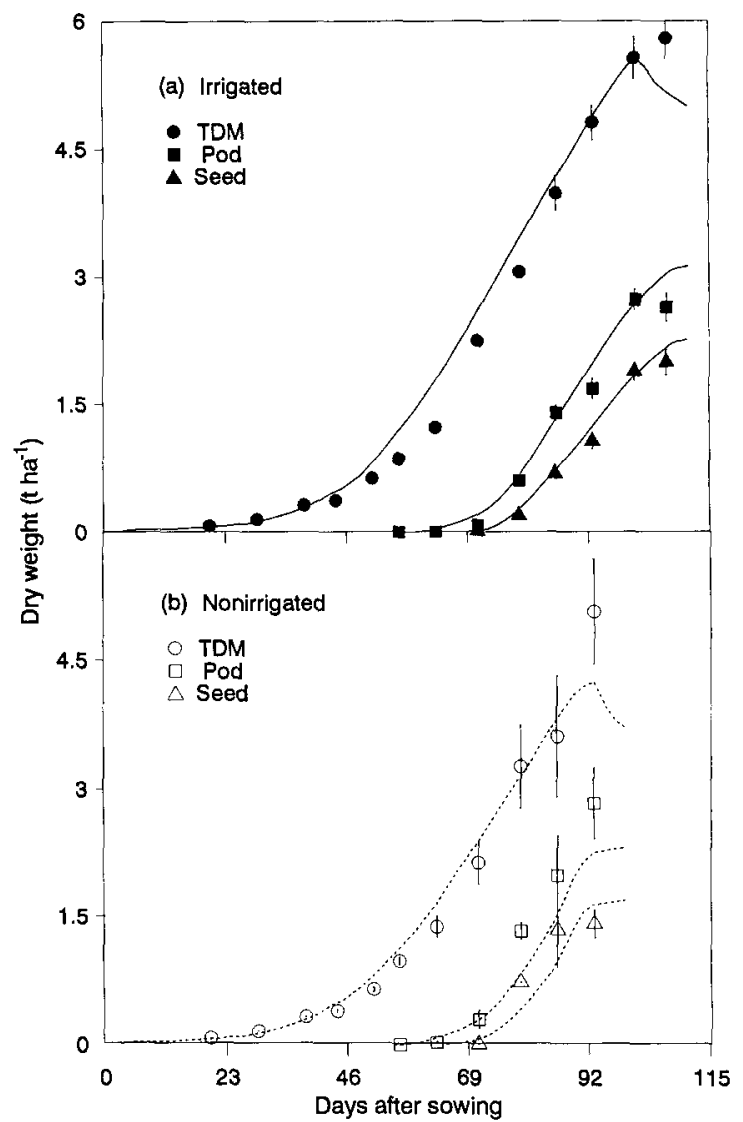

Fig. 8. Simulated (lines) and observed (data points) total dry matter (TDM), pod and seed weights in the (a) irrigated, and (b) nonirrigated treatments during the 1987 season. Vertical bars are twice the standard error of mean.

had been made for the factor PHFAC3 (Fig. 6). These results show that the model is accurate in predicting LAI under irrigated and water-stressed situations, indicating that various processes involved in canopy development ( $\mathrm{V}$-stage development, partition of dry matter to leaves, specific leaf area) and senescence (loss of leaves caused by nitrogen mobilization and water stress) were accurately predicted by the model.

Dry matter production and its partitioning. During 1985 the model accurately predicted total dry matter production (TDM) and partitioning to pods and seeds of cv. Annigeri at various times during the season in the irrigated treatment (Fig. 7a). However, 
the prediction of TDM for the water-stressed treatment was overestimated (Fig. 7b). This could be attributed to decreased uptake of nutrients caused by less nitrogen fixation and low availability of nutrients in the soil under water stress. These processes are not considered in the model at present. Partitioning of biomass to pods and seeds was within the variability observed in the measured values. During 1987, TDM production by $\mathrm{cv}$. JG 74 was overestimated in both the irrigated and water-stressed treatments (Fig. $8 \mathrm{a}$ and $\mathrm{b}$ ). This overestimation may be due to differences in soil fertility between seasons. Dry matter partition to pods and seeds in the irrigated treatment was close to the observed data but was underestimated and slightly delayed in the stressed treatment. Total dry matter and seed yields of cvs. Annigeri and JG 74 at final harvest were significantly correlated $\left(r^{2}=0.89\right.$ for TDM and $r^{2}=0.82$ for seed) with the observed data (Fig. 9). The slopes of the regression lines did not differ from 1.0 and the intercepts did not differ from zero indicating satisfactory predictability by the model for yields at harvest.
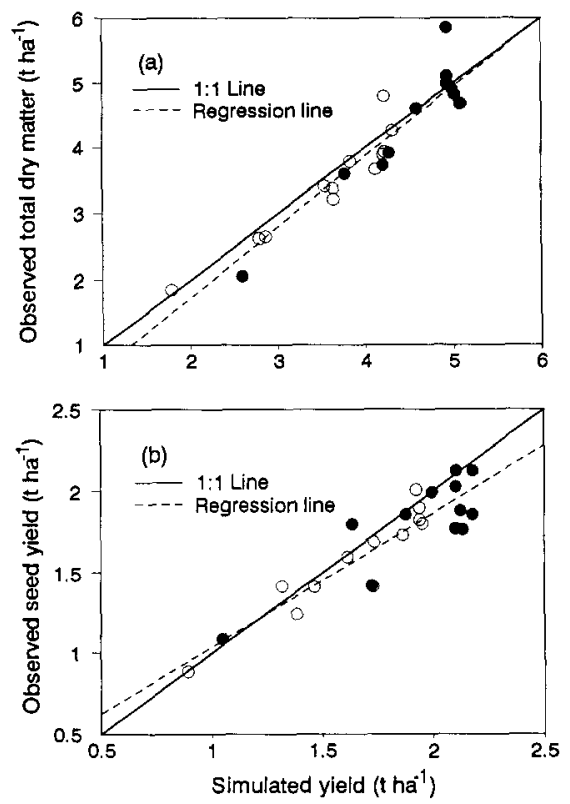

Fig. 9. Simulated versus observed (a) total dry matter (TDM) and (b) seed yields of cvs. Annigeri $(O)$ and $\mathrm{JG} 74(\mathrm{O})$. For TDM: $y=-0.41( \pm 0.331)+1.07( \pm 0.08) x, r^{2}=0.89$, RMSE $=0.336$; For seed yield: $y=0.21( \pm 0.149)+0.83( \pm 0.08) x, r^{2}=0.82$, RMSE $=0.138$.

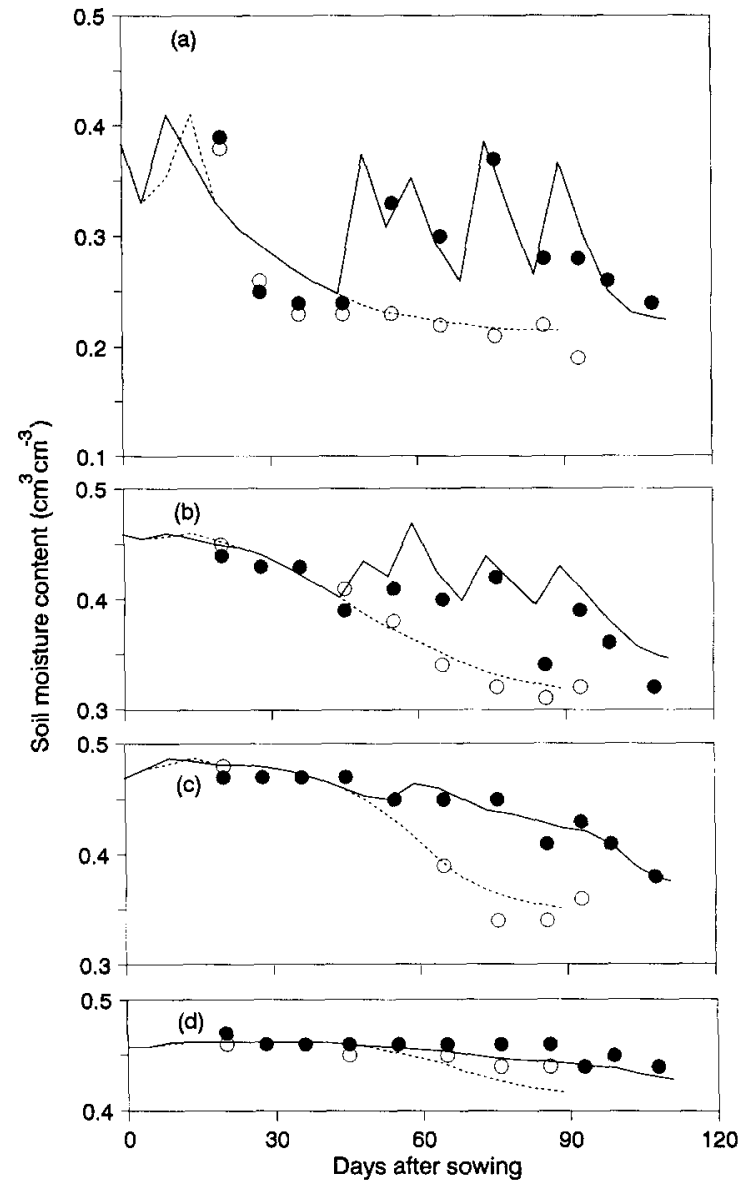

Fig, 10. Simulated (lines) and observed (data points) changes in soil moisture in the (a) $0-18 \mathrm{~cm}$, (b) $18-36 \mathrm{~cm}$, (c) $36-58 \mathrm{~cm}$ and (d) $58-91 \mathrm{~cm}$ soil layers in the irrigated (O-solid line) and nonirrigated ( $\mathrm{O}$-broken line) treatments of the 1992 post rainy season.

Soil moisture. Soil moisture data collected from the irrigated and nonirrigated treatments of the 1992 season experiment were used to illustrate the ability of the model to simulate soil moisture content of the root zone. The model was able to accurately simulate the soil moisture changes (Fig. 10) in the root-zone of the chickpea crop, indicating accurate estimations of root growth and extension and water extraction processes by the model. These results indicate that the model by Ritchie (1985) can accurately predict water balance of the chickpea crop provided soil and crop parameters have been calibrated for a site. 


\section{Conclusions}

It is concluded from this study that the PNUTGRO model provided a good adaptable framework to predict chickpea growth and development. However, some changes in the model and crop parameters file were required to incorporate chickpea crop-specific processes. The resultant model (CHIKPGRO) predicted chickpea phenology, canopy growth, dry matter production and its partitioning, and yields at harvest accurately under water-limiting and nonlimiting situations. Soil moisture changes in the rooting zone were also predicted satisfactorily. The model needs further testing and validation in a wide range of environments before it can be considered fully validated. The present version of the model does not incorporate soil fertility or biological nitrogen fixation, assuming that nutrients are nonlimiting for crop growth. Use of the model under conditions of subop- timal soil fertility would require adjustment of the factor PHFAC3. However the model can be used to predict crop growth and yield under water-limiting and nonlimiting situations.

\section{Acknowledgements}

The authors acknowledge the IBSNAT project for providing the source-code of PNUTGRO. Assistance of M/s S. Ramakrishna, R. Mukunda Reddy, Y.V. Srirama and B.N. Reddy in the conduct of field experiments and that of Mr. K.N.V. Satyanarayana in typing this manuscript is also gratefully acknowledged. This article was submitted as Journal Article No. JA 1824 by the International Crops Research Institute for the Semi-Arid Tropics (ICRISAT). Mention of commercial products does not imply endorsement or recommendation by ICRISAT.

\section{Appendix A}

Major soil and plant processes, parameter values and the source of data for the chickpea model.

\begin{tabular}{|c|c|c|c|}
\hline \multicolumn{2}{|c|}{ Soil or plant process } & \multirow{2}{*}{ Parameter values } & \multirow{2}{*}{$\begin{array}{l}\text { Source of data } \\
\begin{array}{l}\text { As in PNUTGRO } \\
1985)\end{array}\end{array}$} \\
\hline $\mathrm{A}$ & Soil water balance & & \\
\hline B & Root growth and extension & & \\
\hline $\mathrm{i}$ & Root length to weight ratio (RFAC1) & $4550 \mathrm{~cm} / \mathrm{g}$ & as in PNUTGRO \\
\hline ii & Root extension rate (RAFC2) & $3.0 \mathrm{~cm} /$ physiological day & $\begin{array}{l}\text { Estimated from the water ex- } \\
\text { traction data of the } 1984 \text { sea- } \\
\text { son }\end{array}$ \\
\hline iii & Other parameters & - & As in PNUTGRO \\
\hline $\mathrm{C}$ & Vegetative development & & \\
\hline $\mathrm{i}$ & Base temperature $\left(T_{b}\right)$ & $0^{\circ} \mathrm{C}$ & $\begin{array}{l}\text { Siddique et al. (1983), Ellis } \\
\text { et al. (1986) }\end{array}$ \\
\hline ii & Optimum temperature range $\left(\mathrm{T}_{\mathrm{o}}\right)$ & 20 to $30^{\circ} \mathrm{C}$ & $\begin{array}{l}\text { van der Maesen (1972), Cov- } \\
\text { ell et al. (1986) }\end{array}$ \\
\hline iii & Ceiling temperature $\left(T_{c}\right)$ & $55^{\circ} \mathrm{C}$ & As in PNUTGRO \\
\hline iv & Temperature response function & Linear & As in PNUTGRO \\
\hline $\mathrm{D}$ & Reproductive development & & \\
\hline $\mathrm{i}$ & Base temperature $\left(\mathrm{T}_{\mathrm{b}}\right)$ & $0^{\circ} \mathrm{C}$ & $\begin{array}{l}\text { Siddique et al. (1983), Ellis } \\
\text { et al. (1986) }\end{array}$ \\
\hline
\end{tabular}


ii Optimum temperature $\left(\mathrm{T}_{0}\right)$

iii Temperature response function

E Water stress effect on reproductive development

i Water stress function TURF1

ii Water stress function TURF2 $25^{\circ} \mathrm{C}$

Half-sine

Calibration

As in PNUTGRO

$\begin{array}{ll}\text { TURF1 }=(1-\text { TURFAC }) & \text { Calibration } \\ \text { If TURFAC } \leq 0.85 & \text { Calibration }\end{array}$

$\begin{array}{ll}\text { TURF1 }=(1-\text { TURFAC }) & \text { Calibration } \\ \text { If TURFAC } \leq 0.85 & \text { Calibration }\end{array}$

TURF2 $=1.0$

Else TURF2 $=(1-$

TURFAC) $/ 0.15$
F Photoperiod response to flowering

i Critical night length for maximum devel- $13 \mathrm{~h}$ opment rate (VARN1)

ii Critical night length for minimum devel- $20 \mathrm{~h}$ opment rate (VARNO)

G Canopy growth and expansion of leaves

i Water deficit function (SWBAR) for leaf expansion

ii Temperature function (YSLA)

Other functions for estimating canopy height and width

H Photosynthesis

i Response to temperature

ii Response to leaf $\mathrm{N}$ concentration

Minimum $\mathrm{N}$ in leaves (Nbase)

Optimum $\mathrm{N}$ in leaves (Nopt)

Response function

iii Response to water deficit

Water stress factor (SWFAC)

iv Other response functions and parameters

I Respiration

i Cost of tissue synthesis for leaf (AGRLF), stem (AGRSTM), root (AGRRT) and pod wall (AGRSD2)

ii Cost of synthesis of seed, including $\mathrm{N} 1.39$ of glucose/g seed assimilation (AGRSD1)
$1.36,1.30,1.32$ and 1.39 of glucose/g tissue, respectively

\footnotetext{
If $\quad$ TURFAC $\geq 1.0 \quad$ SWBAR

$=1.0$

If TURFAC $\leq 0.7 \quad$ SWBAR

$=0.0$

Response function - linear

If Temp. $\geq 21.0^{\circ} \mathrm{C}$ YSLA $=$

1.0

If Temp. $\leq 0.0$ YSLA $=0.0$

Response function - linear
}

As in PNUTGRO

Assumed, to be calibrated and tested

Assumed, to be calibrated and tested

Calibration

As in PNUTGO

As in PNUTGRO

$2.2 \%$

$5.0 \%$

Half parabola

If water supply/demand ratio $\geq 0.75$, SWFAC $=1.0$

Else SWFAC $=$

(supply/demand ratio)/0.75

Based on chemical analysis of leaves

Based on chemical analysis of leaves

As in PNUTGRO

Calibration

As in PNUTGRO

As per Penning de Vries and van Laar (1982)

As per Penning de Vries and van Laar (1982) 
iii Cost of synthesis of seed, when amides are available from protein mobilization (AGRSD2)

iv Other parameters

J Partitioning of biomass to vegetative organs

i Fractional partition to leaves, stems and roots at $\mathrm{V}$-stage zero

$0.97 \mathrm{~g}$ of glucose $/ \mathrm{g}$ seed

$-$

$0.3, \quad 0.25$ and 0.45 respectively

$0.52,0.35$ and 0.13 respectively

0.10

0.40

Fractional partition to stems of vegeta-

tive growth after maximum $\mathrm{V}$-stage

(FRSTMF)

$\mathrm{v}$ Effect of drought stress on partitioning between root and shoot

K Partitioning to reproductive organs

i Pod wall and seed growth parameters

ii Temperature response function for pod wall and seed growth

iii Seed protein content (SDPRO)

$0.216 \mathrm{~g} / \mathrm{g}$ seed

L Protein mobilization

i Initial protein concentration in leaves (PROLFI), stems (PROSTI), pod wall (PROSHI) and roots (PRORTI)

ii Final protein concentration in leaves (PROLFF), stems (PROSTF), pod wall (PROSHF) and roots (PRORTF)

$0.317,0.148,0.15$ and 0.0137 $\mathrm{g}$ protein $/ \mathrm{g}$ tissue, respectively

$0.166,0.042,0.069$ and 0.094

$\mathrm{g}$ protein/g tissue, respectively
As per Penning de Vries and van Laar (1982)

As in PNUTGRO

Gregory (1988), Singh (1991) and calibration

Gregory (1988), Singh (1991) and calibration

Calibration

Calibration

As in PNUTGRO

As in PNUTGRO

As in PNUTGRO

Based on chemical analysis of seeds

Based on chemical analysis of tissues

Based on chemical analysis of tissues

Calibration

Calibration

As in PNUTGRO

\section{References}

Boote, K.J., 1982. Growth stages of peanut (Arachis hypogaea L.). Peanut Sci., 9: 35-40.

Boote, K.J. and Jones, J.W., 1988. Applications of and limitations to, crop growth simulation models to fit crops and cropping systems to semi-arid environments. In: F.R. Bidinger and C. Johansen (Editors), Drought Research Priorities for the Dryland Tropics. International Crops Research Institute for the Semi-Arid Tropics, Patancheru, India, pp. 63-75.

Boote, K.J. and Loomis, R.S., 1991. The Prediction of canopy assimilation. In: K.J. Boote and R.S. Loomis (Editors), Model- 
ing Crop Photosynthesis: From Biochemistry to Canopy. CSSA Special Publication No. 19. American Society of Agronomy and Crop Science Society of America, Madison, WI, pp. $109-140$.

Boote, K.J., Jones, J.W., Mishoe, J.W. and Wilkerson, G.G., 1986. Modeling growth and yield of groundnut. In: Agrometeorology of Groundnut. Proceedings of an International Symposium, ICRISAT Sahelian Center, Niamey, Niger, 21-26 August 1985. International Crops Research Institute for the Semi-Arid Tropics, Patancheru, India, pp. 243-254.

Boote, K.J., Jones, J.W., Hoogenboom, G. and Wilkerson, G.G., 1987. PNUTGRO v1.0, Peanut crop growth and yield model. Technical documentation. Department of Agronomy and Agricultural Engineering, University of Florida, Gainesville, FL, $121 \mathrm{pp}$.

Boote, K.J., Jones, J.W., Hoogenboom, G., Wilkerson, G.G. and Jagtap, S.S., 1989. PNUTGRO v1.02, Peanut crop growth simulation model. User's Guide, Florida Agricultural Experiment Station Journal No. 8420, Gainesville, FL, 76 pp.

Boote, K.J., Jones. J.W. and Singh, P., 1992. Modeling growth and yield of groundnut. In: S.N. Nigam (Editor), Groundnut A Global Perspective. Proceedings of an International Workshop, ICRISAT Center, Patancheru, India, 25-29 November 1991. International Crops Research Institute for the Semi-Arid Tropics, Patancheru, India, pp. 331-343.

Covell, S., Ellis, R.H., Roberts, E.H. and Summerfield, R.J., 1986. The influence of temperature on seed germination rate in grain legumes. I. A comparison of chickpea. lentil, soyabean and cowpea at constant temperatures. J. Exp. Bot., 37: 705-715.

Ellis, R.H., Covell, S., Roberts, E.H. and Summerfield, R.J., 1986. The influence of temperature on seed germination rate in grain legumes. II. Interspecific variation in Chickpea (Cicer arietinum L.) at constant temperatures. J. Exp. Bot., 37: 1503-1515.

Gregory, P.J., 1988. Root growth of chickpea, fababean, lentil and pea and effects of water and salt stresses. In: R.J. Summerfield (Editor), World Crops: Cool Season Food Legumes. Kluwer, Dordrecht, pp. 857-867.

IBSNAT (International Benchmark Soils Network for Agrotechnology Transfer), 1989. Decision Support System for Agrotechnology Transfer (DSSAT), v2.1. Documentation of IBSNAT. Crop model minimum data set entry and retrieval. IBSNAT Project, Department of Agronomy and Soil Science, University of Hawaii, Honolulu, HI.

Jones, C.A. and Kiniry, J.R. (Editors), 1986. Ceres-Maize: A
Simulation Model of Maize Growth and Development. Texas A\&M University Press, College Station, TX, 194 pp.

Khanna-Chopra, R. and Sinha, S.K., 1987. Chickpea: Physiological aspects of growth and yield. In: M.C. Saxena and K.B. Singh (Editors), The Chickpea. CAB International, Wallingford, UK, pp. 163-189.

Penning de Vries, F.W.T. and van Laar, H.H., 1982. Simulation of growth processes and the model BACROS. In: Simulation of Plant Growth and Crop Production. PUDOC, Wageningen, the Netherlands, pp. 114-136.

Ritchie, J.T., 1985. A user-oriented model of the soil water balance in wheat. In: W. Day and R.K. Atkin (Editors), Wheat Growth and Modeling. Plenum, New York, pp. 293-305.

Roberts, E.H., Summerfield, R.J., Minchin, F.R. and Hadley, D., 1980. Phenology of chickpea (Cicer arietinum L.) in contrasting aerial environments. Exp. Agric., 16: 343-360.

Saxena, M.C., 1981. Agronomic studies on winter chickpeas. In: M.C. Saxena and K.B. Singh (Editors), Proceedings of the Workshop on Ascochyta Blight and Winter Sowing of Chickpeas, ICARDA, 4-7 May 1981, Aleppo, Syria. pp. 123-139.

Siddique, K.H.M., Marshall, C. and Sedgley, R.H., 1983. Temperature and leaf appearance in chickpea. Int. Chickpea Newsl., 8: $14-15$.

Singh, P., 1991. Influence of water deficit on phenology, growth and dry matter allocation in chickpea. Field Crops Res., 28: $1-15$.

Sivakumar, M.V.K. and Singh, P., 1987. Response of chickpea cuitivars to water-stress in a semi-arid environment. Exp. Agric., 23: 53-61.

Summerfield, R.J., Minchin, F.R., Roberts, E.H. and Hadley, P., 1980. The effects of photoperiod and air temperature on growth and yield of chickpea (Cicer arietinum L.). In: Proceedings of International Workshop, Chickpea Improvement, ICRISAT Center, Patancheru, India, 28 February-2 March 1979. International Crops Research Institute for the Semi-Arid Tropics, Patancheru, India, pp. 121-149.

Summerfield, R.J., Minchin, F.R., Roberts, E.H. and Hadley P., 1981. Adaptation to contrasting aerial environments in chickpea (Cicer arietinum L.). Trop. Agric. (Trinidad), 58: 97-113. van der Maesen, L.J.G., 1972. Cicer L., A Monograph of the Genus with Special Reference to the Chickpea (Cicer arietinum L.), its Ecology and Cultivation. Meded. Landbouwhogesch., Wageningen, 72-10, $342 \mathrm{pp}$. 